\title{
The Centenary of the Industrial Conciliation and Arbitration Act 1894: Some Reflections
}

On 31 August 1994, the Industrial Relations Centre at Victoria University of Wellington hosted "a function to mark" the 100th anniversary of the passing through Parliament of the Industrial Conciliation and Arbitration Act. Guests included present and retired employers, union officials, members of the judiciary and academics. Three speakers were invited to comment on the significance of the Act and their comments are reproduced below. Noel Woods is a former Secretary of Labour who, on his retirement from the Department of Labour, was appointed Visiting Fellow at the Industrial Relations Centre where he played a very important role in the Centre's early work. Ken Douglas is President of the New Zealand Council of Trade Unions. Anne Knowles is Deputy Chief Executive of the New Zealand Employers Federation. Both serve on the Industrial Relations Centre's Advisory Committee.

These introductory notes were prepared for the Journal by Associate Professor Raymond Harbridge.

\section{Comments on the Industrial Conciliation and Arbitration Act 1894}

\section{Noel Woods}

Broadly we may look at the Industrial Conciliation and Arbitration Act in two different ways. We may see it as providing a mechanism for minimising wasteful strife through the continual adjustment of wages and conditions of employment to changing economic situations; and as the successful innovator of such things as General Wage Orders and Standard Wage Pronouncements, the 40-hour week, and the basic family wage. It was served by some very distinguished people and built up a solid and useful base of case law. We cannot downplay such achievements.

But there can be another view of the Act, looking at its role as the parent of industrial relations organisations. It adopted this family while they were still very young. How did they develop under its parentage? Before we consider the terms and effectiveness of the adoption of these infant bodies, however, it will be useful to look back to some important pre-natal influences.

Let me take you back some 40 years before the Act was passed - to the time when New Zealand, apart from Maoridom, was mainly a series of prim and proper British settlements where master and servant was a well-established and respected relationship, and also a very personal and mostly comfortable one. 
Then, in 1861, gold was discovered in Central Otago and tens of thousands of people came flooding into New Zealand. These gold seekers were, in general, independent rough-living people who had little experience of, and less respect for, a master and servant relationship. They came tumbling into the prim and proper settlements, but rushed hurriedly through them to get to the gold. Their arrival had little immediate effect on the settlements.

We can move on a few years to around 1870 when the Vogel Government set out to link up the somewhat isolated settlements by a national railways system. This required the establishment of large public works camps out in the wide open spaces. To man the camps Vogel brought in tens of thousand of immigrants. As with the gold seekers, these newcomers passed swiftly through the prim and proper settlements without disturbing them significantly. Unlike the gold seekers, these newcomers were ingrained with the master and servant relationship. In public works camps this relationship was, however, essentially impersonal.

So, by the mid-1870s there were in their separate areas the people in the prim and proper settlements, the rough-and-tumble people in the gold-fields, and the mass-employed people in the public works camps.

Then two things happened with dramatic effect.

The surface gold was worked out and the miners were thrown back into the settlements. Recession hit the Government, the public works camps had to be closed, and the labourers were thrown back into the settlements.

British craft unions (carpenters, engineers, printers) had established themselves in the settlements quite early, generally living peacefully in a comfortably close relationship with employer. Across the Tasman, however, a very different type of trade unionism was establishing itself - the industrial unionism of the seafarers, watersiders, miners, transport workers. These were aggressive unions bent on taking combined action against employers who were loath even to recognise them. Through the trans-Tasman link-up of the Maritime Council this Australian influence entered New Zealand.

In the late $1880 \mathrm{~s}$ in New Zealand we thus had an incongruous mix of abrasive ingredients overwhelming the prim and proper settlements of the $1860 \mathrm{~s}$. In a climate of deepening depression and increasing unemployment these were thrown into the pot and brought to the boil when the ship Corinna, declared black in Sydney, arrived in New Zealand and precipitated the Maritime Strike of 1890.

New Zealanders had never faced any confrontation so large, so threatening, so dangerous. With no experience to guide them they turned to Parliament to protect them. And Parliament, also without experience and after three years of debate, gave them the Industrial Conciliation and Arbitration Act of 1894. The title might have been more accurate if it had placed "conciliation" as an appendage to arbitration. In the debate on the Bill speaker after speaker made it clear that they envisaged an all-powerful court which would protect the community from industrial strife. 
The only trade unions to be recognised would be small, local or single-district unions. The law did not allow unions to provide any training, welfare, or educational facilities for their officers and members. Later, in the 1920 s, even subscriptions became limited by law.

The Act imposed on New Zealand a disintegrated, weak, poverty-stricken and untrained trade unionism. This inevitably influenced organisational attitudes and patterns on the employer side. It was not until the late 1930 s that a multi-district or a national union would be recognised; and it was not until the 1960 s that the Act was amended to allow trade unions to engage in training, welfare and educational activities.

In contrast to this, come back with me into the 1930s. I spent 1936 and 1937 working in the area of front-line relationships in some of the largest enterprises in Great Britain and Europe - Metropolitan Vickers, Reynold and Coventry, ICI, Stock and Company in Berlin, I.G. Farbenindustrie in Bitterfeld. I met with trade unions, like the Transport and General Workers Union in Great Britain, which had already established their own training institutions for officers, shop-stewards and members, and with employers who had no hesitation in encouraging these trade union training activities. I was amongst industries where employers had established continuing consultation with trade unions in various ways. When I returned to New Zealand at the end of 1937 the contrast hit me hard. Compared with what I had been working amongst, New Zealand was - with some exceptions primitive stuff; hundreds of small unions kept small and ignorant and poverty-stricken by the law.

Let me recall to you a conversation I had in more recent years with the president of one of the big trade unions of Western Europe. I had asked him why his union apparently never used the strike as a leverage in wage bargaining. Membership of the union was voluntary; they didn't like conscripts, he said. It had close to a million members. He pointed out that it was financially strong. In its headquarters it was able to employ a team of experts (economists, accountants, statisticians, and so on) equal to the best that either the employers or the government could field. They paid the market price to get the best. This team of experts had the fullest possible range of information, national and international, including information willingly supplied by the employers - note "willingly".

When an agreement came up for re-negotiation the union set its team of experts the task of producing a budget for the industry or enterprise for the next two years. Their prime objective was to keep that industry or enterprise strong in the market place. If they didn't do that there could be no wage increase or even jobs to argue about.

The union knew that the employers would have their experts doing the same exercise with equal competence, the same information, and with the same objective. By agreement the two budgets were tabled and naturally there would be substantial agreement between them. Should there be a major discrepancy the parties would not commence negotiations until a joint working party had sorted out the problem. There was no place for a strike in such proceedings.

If the apparition of a trade union of such size and strength were to appear on the New Zealand horizon, it is not difficult to imagine employers from the Business Roundtable down screaming their heads off to government in sheer fright. But don't worry. The 
prospects of such an apparition are still remote. The children of the Industrial Conciliation and Arbitration Act at 40 years of age were still stunted dwarfs and were nearly 70 before they were allowed to go to school. Institutionally the Act had provided us with protection against growing up.

\section{The Industrial Conciliation and Arbitration Act 100 Years On}

\section{Ken Douglas}

The Industrial Conciliation and Arbitration Act was a landmark in New Zealand's history. Few laws have had as profound an impact on our country's economy and society. The essential principles of the arbitration system provided the framework of our industrial laws right up to the passing of the Employment Contracts Act.

I want to look at New Zealand's experience of arbitration from the point of view of assessing the values and philosophy of that experience.

As everyone here will know, the IC \& A Act was one of the reforms passed by the Liberal Government, which created the framework of the modern Welfare State. The Liberals were determined that the new society of New Zealand should avoid the evils of the Industrial Revolution in Britain. When, in the early 1890 s, it had become apparent that similar abuses were happening in New Zealand, the state accepted that it had a responsibility to provide the social protections for citizens. The Liberals' vision was of a society in which people were empowered to stand on their own feet.

The actual intentions of the architects of the Arbitration Act are less clear and several questions remain unanswered.

Was the IC \& A Act a far-sighted, radical law which gave legal recognition to trade unions, certainly in exchange for renouncing the right to strike?

Was arbitration a system which would produce equity, justice and a steady progression of living standards and quality of life for the workers of Maoriland?

Or was it simply a pragmatic response to establish a mechanism to stop the skill-short economy from being exploited by organised labour?

Noel Woods has given a view that it was not progressive.

In the 1930s Angus McLagan, a communist and miners' leader who later became the first President of the New Zealand Federation of Labour and then Minister of Labour in the late 1940s, wrote an agitational pamphlet in which he described the Arbitration Court as "Labour's Leg Irons". 
in it he asked the question: "What is there to arbitrate between the robbers and the robbed?" Like the early militant union and socialist agitators, he argued for the abolition of the capitalist wages system.

As a young worker leaving Wellington College in 1953, McLagan's pamphlet made a lot f sense to me. Very fresh in my mind was our family's experience of 1951 when my ather and four brothers had been black-listed from truck driving because, as members of he Wellington Drivers Union, they struck in support of the locked out watersiders.

My first experience of the Arbitration Court was in the early 1960s. The Drivers Union ad claimed a 10 minute paid smoko in our award negotiations, a claim which the employers had rejected in conciliation.

We appeared before Judge Tyndall. On the first day the court started at $10 \mathrm{am}$. There was 20 minute break at $11.15 \mathrm{am}$ and the court knocked off for a two hour lunch break at 1pm. Around $4.15 \mathrm{pm}$ there was another 20 minute break and the court finished sitting about $5.30 \mathrm{pm}$.

Given that diligent attention to meal and tea breaks, I thought we would be home and hosed. However our claim was knocked back. Drivers were furious so they all took morning and afternoon smoko. The next year the employers wrote the provision into the award.

It seems to me that it is no longer important what the motivation of the architects of the Arbitration Act really was.

What they certainly were articulating was the need to shift from a legal process based on property relations to a system that was influenced by human values, needs, dignity and respect.

These ideas were certainly not unique to New Zealand. The 1890 s were a time when labour and socialist movements were growing world-wide. At the same time there was a movement for international co-operation to protect workers' rights. This culminated in 1919 in the formation of the International Labour Organisation, an event not disconnected from the fact that the Russian revolution had occurred and Bolshevism was an idea that needed to be confronted.

Twenty-five years later the International Labour Conference defined the ILO's aims and objectives in the post-war world. Walter Nash, the president of the conference, took a direct hand in writing the Declaration of Philadelphia which summed up the ILO's fundamental principles in the following terms:

L Labour is not a commodity.

- Freedom of expression and of association are essential to sustained progress.

- Poverty anywhere constitutes a danger to prosperity everywhere.

The essence of the ILO's approach to labour legislation is that workers have the right to form unions which must have the ability to negotiate collectively with employers. The 
emphasis is on rights and processes, not outcomes. However, for much of its history Net Zealand's arbitration system was about outcomes. Compulsory unionism, compulsor arbitration and the system of horizontal relativities were integral parts of a wider economi policy in which New Zealand was insulated from changes in the world economy.

The collapse of that wider policy meant the inevitable demise of the arbitration system a the collapse of the justifications for the strong element of compulsion that underpinned arbitration system.

On the 100th anniversary of the passing of the IC \& A Act, we can reflect that the whe of history has almost turned full circle. There is no longer a constituency in our country for heavy-handed state intervention in industrial relations. But nor is there majority suppor for either the philosophy or the results of the Employment Contracts Act. Public opinior polls have been universal in finding that a majority of New Zealanders are opposed to th Act. They oppose it because it is unfair: it gives too much power to employers and i allows the vulnerable to be ripped off.

The architects of the 1894 IC \& A Act and the founders of the ILO were motivated humanitarian and democratic values which emphasised empowerment of workers, prescriptions. When the Employment Contracts Act is replaced, and that time is not far off we will find that those values remain fresh and relevant to designing fair and equitable employment legislation.

Our future will be the richer because of the experience of the past 100 years. We still havi to achieve the balance between labour and capital that underpinned some aspects of the thinking behind the IC \& A Act. This remains the task for today and tomorrow.

\section{The Industrial Conciliation and Arbitration Act Centenary}

\section{Anne Knowles}

Victoria University is to be congratulated for organising this function marking the centenar of the passing of the Industrial Conciliation and Arbitration Act, giving as it does, opportunity for us to reflect how the industrial relations framework has developed in th past and where it is likely to move in the future.

As a preface I would note that the Bill was in fact introduced in 1891. It would appear tha the move to enfranchise women, the celebration of that centenary having taken place las year, may have delayed the focus on the industrial relations legislation before the House. It is interesting that despite the focus on women taking precedence then, in looking at those present tonight, it is obvious that women have not in fact participated in great numbers the formal structures of our industrial relations systems.

I am sure, however, that the emphasis must have been on quality not quantity! 
It is fitting that the New Zealand Employers Federation is represented here tonight. We owe our existence to the centralised system introduced by the new conciliation and arbitration procedures of the 1894 Act. There were interesting predecessors - in line perhaps with Noel Wood's explanation of the singular groups in rural New Zealand. A rather novel Napier association, entitled the "Free Association of Employers and Workmen in Hawkes Bay" aimed for "the thoroughly efficient protection of free labour against the attacks of illegitimate unionism" and to bring "unionism back into its old and legitimate channels in which it was a power for good instead of for widespread mischief."

At the establishment of the New Zealand Employers Federation in 1902, the President of the Auckland Employers Association, Mr J.C. Macky said:

Another important part of our work is to educate public opinion as to the trend and effect of labour legislation on the industries and trade of the colony. It is high time the public were enlightened as to the real meaning of our labour laws, and taught the rudiments at any rate of political economy. The most extraordinary ignorance of these simple but vitally important matters prevails on every hand.

I am tempted to ask: "Has anything changed?"

The Industrial Conciliation and Arbitration Act was a product of its times and for many years had a useful function to perform. But as New Zealand has moved from a protected to a competitive economy the inability of a centralised system of industrial relations to keep pace became increasingly apparent. We must celebrate the positive achievements of the Act and its successors but we cannot live in the past.

A recent $O E C D$ report identified rigid labour laws and inflexible labour policies as, among other things, important causes of unemployment in industrialised countries, particularly those of Europe. Such rigidities, the report notes, are increasing, although the times demand flexibility.

By contrast, New Zealand's industrial relations legislation now recognises that need for flexibility to which the report refers. We must respect the past but our job now, as employer representatives and employee representatives, is to foster co-operation between employers and employees, to ensure that an approach that focuses on the viability and needs of all of those at an enterprise replaces the conflict approach of which the Industrial Conciliation and Arbitration Act was the embodiment. 


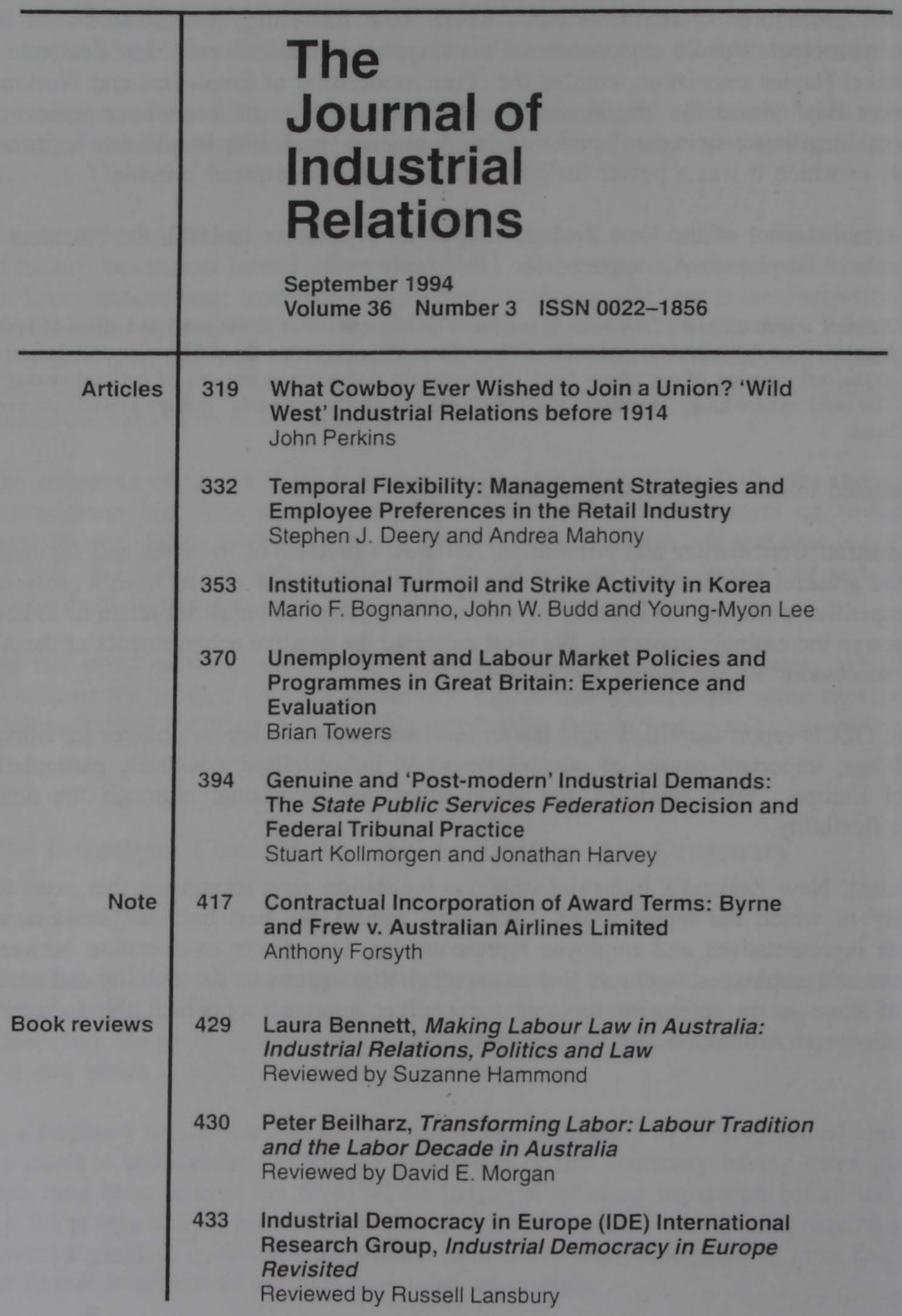

